\title{
ASTHMA EXACERBATIONS AND SYMPTOM VARIABILITY IN CHILDREN DUE TO SHORT-TERM AMBIENT AIR POLLUTION CHANGES IN OSTRAVA, CZECH REPUBLIC
}

\author{
Helena Velická1, Vladimíra Puklová1, Josef Keder², Marek Brabec ${ }^{1,3}$, Marek Malý1, ${ }^{3}$, Martin Bobák4, Bohumil \\ Kotlík ${ }^{1}$, Vítězslav Jiř́k ${ }^{5}$, Vladimír Janout ${ }^{5}$, Helena Kazmarová ${ }^{1}$ \\ ${ }^{1}$ National Institute of Public Health, Prague, Czech Republic \\ ${ }^{2}$ Czech Hydrometeorological Institute, Prague, Czech Republic \\ ${ }^{3}$ Institute of Computer Science, Czech Academy of Sciences, Prague, Czech Republic \\ ${ }^{4}$ University College London, London, United Kingdom \\ ${ }^{5}$ Department of Epidemiology and Public Health, Faculty of Medicine, University of Ostrava, Ostrava, Czech Republic
}

\section{SUMMARY}

Aim: The Ostrava region suffers from high levels of air pollution during winter inversions. We investigated the association between short-term elevations of air pollutant concentrations and worsening of respiratory problems, use of asthma medication and restriction of daily activities in asthmatic patients in Ostrava.

Methods: One-hundred and forty-seven child and adolescent patients (aged 6-18 years) with a confirmed diagnosis of mild to moderate persistent asthma were included in the study. Participants' parents completed diaries covering the period of November 2013 to February 2014; this analysis included 18,228 person-days. Daily smoothed maps of outdoor concentrations of particulate matter $\left(\mathrm{PM}_{10}\right)$, nitrogen dioxide $\left(\mathrm{NO}_{2}\right)$ and sulphur dioxide $\left(\mathrm{SO}_{2}\right)$ were constructed from routine monitoring data, and participants' daily exposures were estimated on the basis of time spent at home and at school. The associations between health outcomes and exposure to air pollutants were estimated using the multiple logistic regression method.

Results: The odds ratios (OR) of the combined outcome for wheezing and/or difficulty in breathing, per $10 \mu \mathrm{g} / \mathrm{m}^{3}$ increase in the mean $24-\mathrm{h}$ exposure were 1.07 (95\% confidence interval 1.04-1.11) for $\mathrm{PM}_{10}, 1.30$ (1.18-1.44) for $\mathrm{NO}_{2}$, and 1.37 (1.18-1.59) for $\mathrm{SO}_{2}$. Additional inhaler use (in addition to usual medication) was also more frequent at higher air pollutant concentrations; the odds ratios per $10 \mu \mathrm{g} / \mathrm{m}^{3}$ increase in the mean 24-h exposure were 1.05 (1.02-1.07) for $\mathrm{PM}_{10}, 1.19(1.10-1.30)$ for $\mathrm{NO}_{2}$, and 1.26 (1.11-1.43) for $\mathrm{SO}_{2}$. Associations were less consistent for other health outcomes.

Conclusions: These results suggest moderately strong associations between air pollutant concentrations and respiratory difficulties among asthmatic children and adolescents. More detailed analyses are required to confirm these preliminary findings.

Key words: asthma, air pollution, short-term exposure, respiratory symptoms, children

Address for correspondence: H. Velická, National Institute of Public Health, Šrobárova 48, 10042 Prague 10, Czech Republic. E-mail: helena. velicka@szu.cz

\section{INTRODUCTION}

The effect of a short-term increase in air pollutant concentrations on asthma worsening is the subject of a number of previous studies. A positive association has been found between respiratory asthma symptoms and the increased concentrations of $\mathrm{SO}_{2}$ and $\mathrm{PM}_{10}$ (1), fine suspended particulate matter $\mathrm{PM}_{2.5}$ (particle size $<2.5 \mu \mathrm{m}$ ) (2), or $\mathrm{CO}$ and $\mathrm{NO}_{2}$ (3). A meta-analysis of previous studies has revealed a significant increase in respiratory asthma symptoms of $2.8 \%$ per $10 \mu \mathrm{g} / \mathrm{m}^{3}$ of $\mathrm{PM}_{10}$ and $3.1 \%$ per $10 \mu \mathrm{g} / \mathrm{m}^{3}$ of $\mathrm{NO}_{2}$ (4). The health effects of short-term concentrations calculated per unit of increase vary between studies, possibly reflecting the influences of the long-term exposure level characteristic for a given place and supporting the development of chronic pathologies (5). The delay between a short-term increase in air pollutant concentrations and health effects also varies between studies, although the health effects seem most pronounced on the day of exposure to the increase in air pollution $(1,6-8)$.

In the Czech Republic (CR), the effects of short-term concentrations of air pollution on the respiratory health of asthma patients were studied in the early 1990s in the Sokolov area (9, 10 ), which is characterised by large pollution sources (brown coal power stations and local household heating). Currently, the area with the highest air pollution is the Ostrava-Karviná coal basin (11). For this reason, the present study was based in Ostrava, an industrial city located in the north-east of the Czech Republic (known as the Moravia-Silesia Region). Air pollution in Ostrava is caused primarily by large industrial sources, road traffic, household heating, and cross-border pollution from Poland; other contributing factors that affect the dispersion of air pollution are the unfavourable geomorphology of the region and direction of the prevailing wind. In recent decades, the concentrations of air 
pollutants, especially particulate matter $\left(\mathrm{PM}_{10}\right.$ and $\left.\mathrm{PM}_{2.5}\right)$ and polycyclic aromatic hydrocarbons (PAH), are significantly higher in this area than in other urban areas in the Czech Republic; short-term concentrations of $\mathrm{PM}_{10}$ suspended particulate matter in Ostrava often exceed the limit value. Frequent wintertime inversions result in the accumulation of pollutants in the near-ground layers of atmosphere. The informative and regulatory thresholds for $\mathrm{PM}_{10}$ are regularly exceeded and smog episodes, as defined in Annex No. 6 of the Air Protection Act (12) occur every year during the winter season (13).

The respiratory health of the population in Ostrava has so far only been studied in relation to long-term exposure to polluted air. In 1994-2006, several studies were conducted in Ostrava, focused on respiratory health and air pollution, including the Central European Study of Air Pollution and Respiratory Health (CESAR-PHARE) (14). None of these studies demonstrated a consistent significant relationship between long-term exposure to air pollution and prevalence of allergic diseases including asthma (11), although the programme for monitoring allergy prevalence in children, coordinated by the National Institute of Public Health (NIPH), has confirmed a significantly higher prevalence of childhood asthma in the Ostrava-Karviná conurbation in comparison with 15 other cities in CR (15).

Our study examined respiratory health changes in child/ adolescent and adult asthma patients in relation to daily exposure to ambient $\mathrm{PM}_{10}$ particulate matter, nitrogen dioxide $\mathrm{NO}_{2}$, and sulphur dioxide $\mathrm{SO}_{2}$ during the heating season 2013-2014 in Ostrava. This paper presents the first results from the child/ adolescent cohort.

\section{MATERIALS AND METHODS}

\section{Study Population}

The study subjects were children and adolescents suffering from asthma, patients of paediatric outpatient practices run by eight collaborating allergologists/pneumologists in Ostrava. These physicians addressed the patients' parents at the time of regular check-ups between July 1 and October 31, 2013. The inclusion criteria were as follows: age 6-18 years, permanent residency in the city of Ostrava, confirmed diagnosis of asthma, and asthma severity classified as mild persistent or moderate persistent. In total, 245 children and adolescents (aged 6-11 and 12-18) were enrolled in the study. Their parents/legal guardians signed informed consent and, in cooperation with the physician, completed the entry questionnaire which contained a full battery of Asthma Control Tests (ACT) (16-18) as implemented in the Czech Republic (19). Further questions concerned medication, patient's history of asthma, allergy and eczema, detailed analysis of asthma triggers, smoking habits including exposure to environmental tobacco smoke (ETS), family history of asthma and allergy, lifestyle factors, family socio-economic factors, residential address, school address, and daily patterns of time spent at each of the addresses indicated on working and non-working days.

The asthma diary template was available as a hard-copy or electronically. The second alternative was chosen by 154 (62.9\%) of the study subjects, of which 7 patients subsequently withdrew from the study. The analytical sample therefore consisted of 147 respondents (users of the electronic diary; reasons for this limitation are given below). The symptoms monitored in the diary were cough (any time during the day), breathing difficulties, wheezing, use of inhaler in case of acute need (in addition to regular therapy), restricted daily activities at home and/or at school and/ or in sports due to asthma worsening, contacting a doctor because of acute asthma symptoms, hospital admission and/or absence from school due to asthma exacerbation. Moreover, symptoms of 'burning' mucous membranes (eye, nose and throat) were included in the diary as well as one inverse question (where the positive answer meant "no asthma symptoms"). Fever and/or viral disease, as well as residence outside the Ostrava agglomeration, were also monitored.

The parents/legal guardians participating in this study completed a daily record, consisting of entries for symptoms and changes in health. In a few cases these records were completed by the participants themselves, e.g. teenagers willing to cooperate under parental supervision. The hard copy diaries were distributed to participants by mail, and every other week the collected forms were mailed back to the study coordinator or dropped into a collection box at the doctor's surgery. Electronic forms were filled in on-line; a unique link was e-mailed to the participant's parent/legal guardian once a week. The study was approved by the Ethical Committees of NIPH in Prague, University Hospital in Ostrava and Municipal Hospital in Ostrava.

\section{Exposure Determination}

Concentrations of $\mathrm{PM}_{10}, \mathrm{NO}_{2}$ and $\mathrm{SO}_{2}$ in ambient air were measured by the Czech Hydrometeorological Institute (CHMI). The network of measuring stations in the Moravia-Silesia Region consists of $40 \mathrm{NO}_{2}$ and $\mathrm{PM}_{10}$ stations, and $20 \mathrm{SO}_{2}$ stations. Of this network, 8 stations measuring $\mathrm{PM}_{10}$ concentrations, 6 stations $\mathrm{NO}_{2}$, and 5 stations $\mathrm{SO}_{2}$ are located in Ostrava. These routine monitoring data were used to construct partially smoothed maps of 24-hour concentrations, with a 500 x $500 \mathrm{~m}$ grid resolution. In addition, the output data from the dispersion model for the city of Ostrava, other available complementary data, and records from the stations in the surrounding areas of Ostrava were taken into account. Residential and school addresses of the asthma patients included in the study were digitized (GPS coordinates were linked with GIS). Daily exposure was calculated separately for each participant as the weighted mean of the concentrations of the pollutants monitored, based on the daily patterns of time consisting of the mean lengths of time spent at home and at school. To cover the whole 24-hour period of the day, the $10 \%$ trimmed mean of daily concentrations in all 500 x $500 \mathrm{~m}$ tiles representing Ostrava was added. When a patient left Ostrava for one or more days to stay in another area, as indicated in his/her diary, the exposure for the respective day(s) was determined on the basis of data from the monitoring station representative of the area visited. If the place of the respondent's stay was not indicated in the diary, exposure was determined from the minimal concentration tile of the map of Ostrava for the respective day.

Meteorological data, routinely recorded by an automatic climate station of the Ostrava branch of CHMI in Ostrava-Poruba, were taken as representative of the region of study. The air temperature, relative humidity and wind speed data were combined to calculate apparent temperature (AT). In general, AT reflects 
human perception of outdoor temperature. It is used as an objective measure of thermal comfort and widely applied in studies of weather influence on human health. In this study, AT was estimated according to Steadman's formula (20). The daily mean AT values were obtained from the hourly AT values.

\section{Statistical Analysis}

Data on the presence or absence of various symptoms and other phenomena were analyzed via multiple logistic regression in which pollutant exposure was used. Other important explanatory variables were also included: apparent temperature, working/non-working day indicator (assuming the value of 1 on weekends and holidays, and 0 otherwise) for adjustment. Because the nature of the data is inherently longitudinal (one person is followed throughout the study period), measurements for the same individual have far greater similarity to each other than to the measurements of different individuals (even if various external covariates are accounted for). This complication is treated in a standard way, by the inclusion of random individual effect into the model. Therefore, a logistic model of GLMM (Generalized Linear Mixed Model) class was used (21, 22). All computations (model fitting and testing and related computations) were performed in $\mathrm{R}^{*}$. From the model, the regression coefficient on the exposure was obtained and tested to ascertain whether it was different from 0 (via the likelihood ratio test). The odds ratios (OR) of the health outcomes were calculated for an increase of $10 \mu \mathrm{g} / \mathrm{m}^{3}$ of the mean 24-h exposure to a given air pollutant and adjusted for apparent temperature, working/non-working day factor and random individual effect on the day of exposure (lag 0 ), for each combination of response variable and pollutant separately and the $(95 \%)$ confidence intervals for the odds ratio were estimated.

Symptoms associated with asthma worsening were assessed on the total of person-days (for 147 subjects over 124 days between October 30, 2013 and March 2, 2014, i.e. 18,228 person-days) after exclusion of person-days with indicated occurrence of fever and/or viral disease and/or person-days with missing data. The incidence of fever and/or viral disease as such was assessed for all person-days obtained with valid data.

\section{RESULTS}

The first assessment of the diary data obtained revealed a difference in the response trends between the hard copy diary users and on-line respondents (the reason for this is interpreted in the discussion). For the purpose of statistical analysis only the electronic diaries were used.

Among 147 child and adolescent subjects (mean age 12.2 years, age range 6-18 years), 78.9\% reported allergic disease, most frequently pollinosis $(61.4 \%)$, followed by dust mite allergy (49.0\%), dust allergy (24.1\%), mould allergy (14.5\%), and food allergy $(14.5 \%)$. The most common combination of allergies was pollen, dust, and dust mite allergies, reported by $10.3 \%$ of the respondents. The majority $(80.95 \%)$ of study subjects lived in two-parent families. For more details, including family history, see Table 1.

Table 1. Characteristics of the study population

\begin{tabular}{|c|c|c|}
\hline & $\mathrm{n}$ & $\%$ \\
\hline Number of patients & 147 & 100.0 \\
\hline Boys/girls & $93 / 54$ & $63.3 / 36.7$ \\
\hline Asthma severity (GINA 2/GINA 3) ${ }^{a}$ & $98 / 49$ & $66.7 / 33.3$ \\
\hline Asthma in family history & 76 & 51.4 \\
\hline Pollinosis in family history & 97 & 66.2 \\
\hline Other allergy in family history & 80 & 54.1 \\
\hline No allergy in family history & 33 & 22.2 \\
\hline Lifetime prevalence of atopic eczema & 60 & 41.1 \\
\hline Visit to a doctor due to asthma exacerbation in the last 12 months & 59 & 40.4 \\
\hline Hospital admission due to asthma exacerbation in the last 12 months & 4 & 2.7 \\
\hline Smoking of any parent & 37 & 25.2 \\
\hline Daily exposure to environmental tobacco smoke & 10 & 7.1 \\
\hline Damp and/or mould in dwelling & 24 & 16.4 \\
\hline Pets at home & 93 & 63.3 \\
\hline \multicolumn{3}{|l|}{ Weekends out of Ostrava } \\
\hline Almost never & 28 & 19.1 \\
\hline Sometimes & 96 & 65.2 \\
\hline Most weekends & 23 & 15.7 \\
\hline On holidays - at least 2 continuous weeks outside of Ostrava & 130 & 88.4 \\
\hline Sport regularly & 93 & 63.3 \\
\hline
\end{tabular}

aGlobal Initiative for Asthma; asthma severity scale: GINA 2 refers to mild persistent asthma, GINA 3 refers to moderate persistent asthma.

*The R Project for Statistical Computing is available at: http://www.R-project.org 
Nearly all asthma patients (96.5\%) reported seasonal deterioration of asthma symptoms mostly in the autumn or winter $(20.3 \%$ and $24.5 \%$, respectively), or both in autumn and winter (19.6\%). Febrile disease $(53.1 \%)$, physical strain $(51.0 \%)$, exposure to pollen $(42.9 \%)$, dust $(37.4 \%)$, and cold air $(28.6 \%)$ were identified as the most common asthma triggers, followed by strong emotive reactions, stress, laughter $(17.7 \%)$, pets $(15.0 \%)$, tobacco smoke (13.6\%), mould $(12.2 \%)$, odours $(11.6 \%)$, or food $(4.1 \%)$.

Scores of the Asthma Control Test (ACT) revealed that $30.0 \%$ of the study subjects achieved full asthma control (25 points), $47.1 \%$ partial asthma control (20-24 points), and $22.9 \%$ had poor asthma control (5-19 points). The use of rescue medication to treat acute asthma worsening within a four week period preceding the completion of the entry questionnaire was reported at the following rates: several times a day in $18.5 \%$ of the asthma patients, several times a week in $7.5 \%$, once a week or less in $20.6 \%$, and not at all in $53.4 \%$.

Among participating asthma patients, 97.2\% used their asthma control medication regularly and $83.7 \%$ of them all year round. Most of the asthmatics took combined preparations of inhaled corticosteroids with long-acting $\beta 2$ agonists (34.7\%), supplied with antihistamines $(17.7 \%)$ or in combination with leukotriene receptor antagonists $(8.2 \%)$; inhaled corticosteroids possibly combined with antihistamines or bronchodilators were reported by $24.5 \%$ of patients. In the event of asthma worsening, $53.1 \%$ of subjects reported use of inhaled short-acting $\beta 2$ agonists, $23.1 \%$ of asthma patients used higher doses of their regular medication and $18.4 \%$ of patients combined both of these possibilities.

Health outcomes used in the statistical analysis, as collected for the cohort of 147 children and adolescents during the study period, are summarized in Table 2. The distribution of prevalence of the most frequent asthma symptoms and asthma induced complaints per 100 person-days is characterized, with a detail for the highest percentiles. In Table 3, individual 24-hour exposures of the respondents to $\mathrm{PM}_{10}, \mathrm{NO}_{2}$ and $\mathrm{SO}_{2}$ are presented as averaged over the cohort and over the study period. The temporal pattern of these averaged exposures is presented in Figure 1. The temporal pattern of the prevalence of two of the health outcomes examined below is depicted in Figure 2.

The effect estimates of the association between pollutants and health outcomes, odds ratios (OR), and 95\% confidence intervals

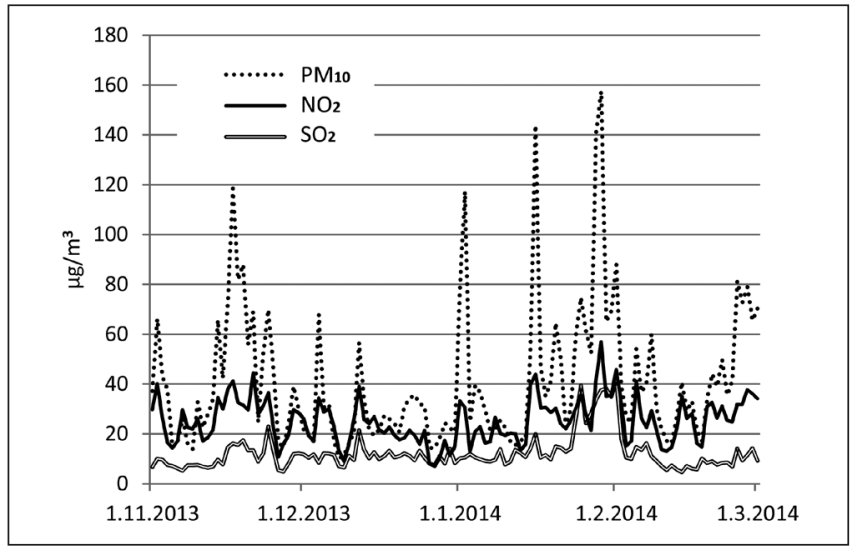

Fig. 1. Temporal pattern of 24- $h$ average exposures to $P M_{10}$ $\mathrm{NO}_{2}$ and $\mathrm{SO}_{2}$ in the period of November 1, 2013 - March 1, 2014.

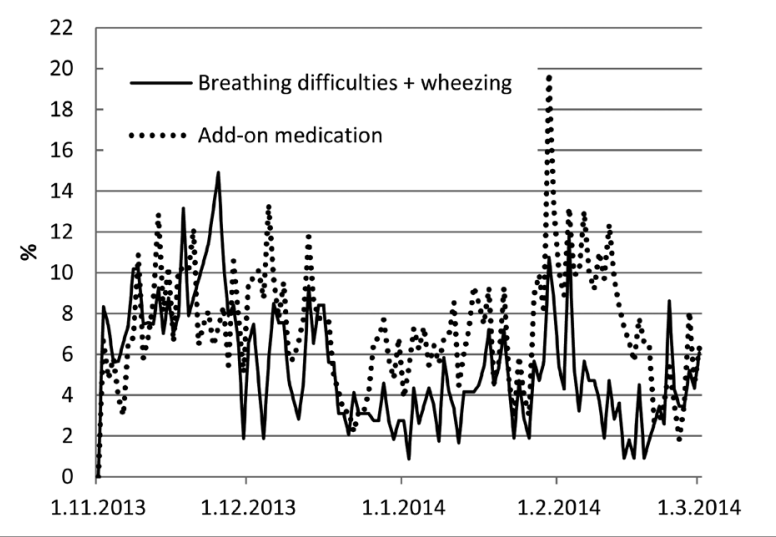

Fig. 2. Time series of daily prevalence of additional medication and breathing difficulties + wheezing in the period November 1, 2013 - March 1, 2014 (per 100 person-days, person-days with fever and/or viral disease excluded)

(95\% CI), are given in Table 4. Cough had an association with $\mathrm{NO}_{2}$ exposure that was on the borderline of significance and there was almost no association with exposure to $\mathrm{PM}_{10}$ and $\mathrm{SO}_{2}$. Breathing difficulties and wheezing (as a combined category) were significantly $(\mathrm{p}<0.001)$ associated with increased concen-

Table 2. Distribution of asthma symptoms and asthma induced complaints daily prevalence (per 100 person-days)*

\begin{tabular}{|c|c|c|c|c|c|c|c|}
\hline Health outcome & $\begin{array}{c}\text { Number of } \\
\text { person-days }\end{array}$ & $\begin{array}{c}25 \text { th } \\
\text { percentile }\end{array}$ & Median & $\begin{array}{c}\text { 75th } \\
\text { percentile }\end{array}$ & $\begin{array}{c}\text { 95th } \\
\text { percentile }\end{array}$ & Maximum & Mean \\
\hline Cough & 13,444 & 13.0 & 15.8 & 19.3 & 26.1 & 30.8 & 16.6 \\
\hline Breathing difficulties & 13,444 & 2.6 & 4.0 & 5.6 & 8.7 & 14.2 & 4.4 \\
\hline Wheezing & 13,448 & 0.9 & 1.0 & 1.9 & 3.5 & 4.4 & 1.4 \\
\hline Inhaler use (in case of acute need) & 12,972 & 5.5 & 6.9 & 9.2 & 12.3 & 19.8 & 7.2 \\
\hline \multicolumn{8}{|l|}{ Restricted activities } \\
\hline At home & 13,444 & 4.3 & 6.1 & 8.7 & 11.4 & 14.1 & 6.5 \\
\hline At school & 13,444 & 0.8 & 2.8 & 6.6 & 9.7 & 12.1 & 3.5 \\
\hline In sports & 13,444 & 2.6 & 4.9 & 6.5 & 8.6 & 9.4 & 4.5 \\
\hline Absence from school & 13,195 & 0.0 & 0.9 & 1.9 & 3.9 & 5.6 & 1.2 \\
\hline
\end{tabular}

*person-days with fever and/or viral disease excluded 
Table 3. Distribution of 24-hour mean exposures during the study period

\begin{tabular}{|l|c|c|c|c|c|c|}
\hline Pollutant exposure & 25th percentile & Median & 75th percentile & 95th percentile & Maximum & Mean \\
\hline $\mathrm{PM}_{10}$ exposure $\left(\mu \mathrm{g} / \mathrm{m}^{3}\right)$ & 21.0 & 32.0 & 52.6 & 92.2 & 223.4 & 40.9 \\
\hline $\mathrm{NO}_{2}$ exposure $\left(\mu \mathrm{g} / \mathrm{m}^{3}\right)$ & 17.2 & 24.4 & 32.8 & 45.3 & 71.6 & 25.2 \\
\hline $\mathrm{SO}_{2}$ exposure $\left(\mu \mathrm{g} / \mathrm{m}^{3}\right)$ & 7.3 & 10.4 & 14.5 & 31.2 & 57.5 & 12.2 \\
\hline
\end{tabular}

Table 4. Pollutant exposure effects* upon various health outcomes - expressed as odds ratios (OR for an increase of $10 \mu \mathrm{g} /$ $m^{3}$ of the mean $24-h$ exposure)

\begin{tabular}{|l|c|c|c|c|c|c|c|c|c|}
\hline \multirow{2}{*}{ Prevalence of } & \multicolumn{3}{|c|}{ PM $_{10}$} & \multicolumn{3}{|c|}{$\mathrm{NO}_{2}$} & \multicolumn{3}{c|}{$\mathrm{SO}_{2}$} \\
\cline { 2 - 11 } & OR & $95 \% \mathrm{Cl}$ & $\mathrm{p}$-value & OR & $95 \% \mathrm{Cl}$ & $\mathrm{p}$-value & OR & $95 \% \mathrm{Cl}$ & $\mathrm{p}$-value \\
\hline Cough & 0.99 & $0.97-1.01$ & 0.42 & 1.06 & $1.00-1.12$ & 0.04 & 0.97 & $0.89-1.06$ & 0.54 \\
\hline Breathing difficulties and/or wheezing & 1.07 & $1.04-1.11$ & $<0.001$ & 1.30 & $1.18-1.44$ & $<0.001$ & 1.37 & $1.18-1.59$ & $<0.001$ \\
\hline Inhaler use $^{\#}$ & 1.05 & $1.02-1.07$ & $<0.001$ & 1.19 & $1.10-1.30$ & $<0.001$ & 1.26 & $1.11-1.43$ & $<0.001$ \\
\hline Restricted activities $^{\$}$ & 1.02 & $1.00-1.04$ & 0.10 & 1.13 & $1.06-1.21$ & $<0.001$ & 1.09 & $1.00-1.20$ & 0.09 \\
\hline Fever $^{\dagger}$ & 0.99 & $0.97-1.01$ & 0.15 & 1.00 & $0.94-1.05$ & 0.78 & 1.04 & $1.00-1.12$ & 0.41 \\
\hline
\end{tabular}

*adjusted for apparent temperature, working/non-working day factor, and random individual effect

\#in case of need, add-on medication (in addition to regular therapy)

\$at home and/or at school and/or in sports

tand/or viral disease - in this calculation considered as dependent variable - possible health outcome of air pollution, otherwise considered as a confounder

trations of any of the airborne pollutants monitored. The same is true for the use of add-on medication. Increased average daily exposure to airborne pollutants is associated with the highest odds of increase in the prevalence of breathing difficulties and wheezing in childhood/adolescent asthma patients; a $10 \mu \mathrm{g} / \mathrm{m}^{3}$ increase in $\mathrm{SO}_{2}$ and $\mathrm{NO}_{2}$ was associated with a $37 \%$ and $30 \%$ increase in the odds, respectively. The odds of using reliever add-on medication to control asthma worsening were also the highest with increased exposure to the gaseous airborne pollutants $\mathrm{SO}_{2}$ and $\mathrm{NO}_{2}$. Restricted daily activities (combined category of restricted daily activities at home and/or at school and/or in sports) were significantly associated with increased mean 24-h exposure to $\mathrm{NO}_{2}$ but not with $\mathrm{PM}_{10}$ and $\mathrm{SO}_{2}$. The presence of fever and/or viral disease, considered as a dependent variable - the possible health outcome of air pollution - was not significantly associated with increased mean 24-h exposure to any of the airborne pollutants in question.

Data not presented in Tables: some indicators of asthma worsening appeared to be rare, e.g. contacting a physician (prevalence of $0.2 / 100$ person-days). Burning mucous membranes, although the total prevalence rate reached 5.5 cases $/ 100$ person-days, were not significantly associated with increased mean 24-h exposure to any of the airborne pollutants monitored. In an inverse question (where the positive answer meant "no asthma symptoms") there was a significant $(\mathrm{p}=0.001)$ negative relationship with an increase by $10 \mu \mathrm{g} / \mathrm{m}^{3}$ in mean 24 -h exposure to $\mathrm{NO}_{2}$ (OR $0.92,95 \%$ CI $0.88-0.97$ ), and non-significant relationships with $\mathrm{PM}_{10}$ (OR 0.99, 95\% CI 0.97-1.003) and $\mathrm{SO}_{2}$ (OR 0.99, 95\% CI 0.92-1.07).

In the last five years (winter periods 2009/2010 through $2013 / 2014$ ), the mean monthly pollutant concentrations in November, December, January and February ranged between 40 and $130 \mu \mathrm{g} / \mathrm{m}^{3}$, and the total of days when the 24-hour concentration of $50 \mu \mathrm{g} / \mathrm{m}^{3}$ was exceeded in this period varied between the measuring stations from 42 to 82 days. The analysis of seasonal variation in air pollution from $\mathrm{PM}_{10}$ suspended particulate matter in 2006 through 2011 shows a gradual escalation in the number of exceedance days (the 24-hour mean above $\left.50 \mu \mathrm{g} / \mathrm{m}^{3}\right)(23)$. The situation in winter $2013 / 2014$ fell outside this trend: the winter weather was unusually mild in comparison with previous years. The monthly means of $\mathrm{PM}_{10}$ concentrations recorded by the stationary measuring stations in Ostrava varied between 31 and $71 \mu \mathrm{g} / \mathrm{m}^{3}$ and the total of exceedance days (above $50 \mu \mathrm{g} / \mathrm{m}^{3}$ ) ranged from 28 to 37 days, with the exception of one station which registered 69 exceedance days. At the same time, the maximum hourly $\mathrm{PM}_{10}$ concentrations were substantially lower, reaching around $250 \mu \mathrm{g} / \mathrm{m}^{3}$ in the winter season 2013/2014, as compared to $500-600 \mu \mathrm{g} / \mathrm{m}^{3}$ recorded in the previous seasons.

\section{DISCUSSION}

This study examines the relationship between short-term fluctuations in air pollutant concentrations and the respiratory health of children and adolescents diagnosed with asthma. Significant associations were observed between exposure to pollutants and asthma-related outcomes despite the unusually mild winter in Ostrava in 2013/2014. Higher concentrations of $\mathrm{SO}_{2}, \mathrm{NO}_{2}$, and $\mathrm{PM}_{10}$ were associated with more frequent asthma symptoms and medication use, and higher $\mathrm{NO}_{2}$ concentrations were also associated with restricted daily activities due to asthma worsening.

The pollutants selected are the classic airborne pollutants that are considered to be triggers of acute asthma symptoms, with the exception of ozone since the study was completed in winter. The heating season was selected as the period when heavy air pollution episodes usually occur. At the same time, there is less pollen in the air, a common trigger of allergic asthma. However, the influence of pollen during the heating season cannot be completely ruled out because pollen components were detected in urban airborne dust samples even during winter (24).

According to information provided by both physicians and parents, the patients under study received higher doses of their 
regular medication in order to better cope with smog episodes which were expected but did not occur in 2013/2014. As a result, not only the trigger of asthma symptoms was reduced but also a lot of symptoms might have been prevented or veiled by higher doses of medication. This may have masked some potential links to air pollution. On the other hand, use of single-pollutant model leads to an overestimation of the effect of each pollutant considered despite the fact that these pollutants may act synergistically.

As for the selection of the respondents, the parents/legal guardians of all asthma patients who met the enrolment criteria were addressed; nevertheless, it can be assumed that there was a greater likelihood of consent for participation in the study from the more parentally involved parents/guardians. It is known that patients with poorly controlled asthma have a stronger response to air pollution $(8,25)$; therefore, the participation of more caring parents in this study may have biased the effect of air pollution on asthma symptoms which might appear lower in comparison with the agematched general population with comparable asthma severity.

The parental education level in the present study was markedly above average of the adult population of Ostrava: the paternal or maternal education level percentages in comparison with those of the general population were $28.0 \%$ and $27.3 \%$, respectively, vs. $15.7 \%$ for tertiary education; $32.2 \%$ and $50.0 \%$, respectively, vs. $31.2 \%$ for secondary education; and $39.8 \%$ and $22.7 \%$, respectively, vs. $53.1 \%$ for primary education, as derived from the Socioeconomic Atlas of the Moravia-Silesia Region (26).

Among the respondents, a distinct difference was revealed between the answers completed in the hard-copy diaries and the ones completed on-line. The two groups of respondents did not significantly differ in age, gender, asthma severity or in responses to the entry questionnaire items, with the exception of a single question concerning asthma triggers: the hard-copy respondents reported cold air to be an asthma trigger slightly more often, at borderline statistical significance $(p=0.041)$. The on-line diary appears to have been superior to the hard-copy version, as it needed to be completed regularly (it could not be filled in retrospectively for periods longer than one week); the health data entered were therefore assumed to be more accurate.

Fever and/or viral disease can be considered as a confounder in the study of asthma symptoms or asthma exacerbation. Therefore, all person-days when fever or viral disease was reported were excluded. However, some authors considered acute respiratory diseases (including fever and/or viral disease) or higher morbidity as a consequence of impaired immunity in asthma or even as a consequence of air pollution $(8,9)$. In this study, fever and/or viral disease were also assessed in relation to air pollution exposure (in the data set including the person-days with reported fever and/or viral disease). The relationship between fever and/or viral disease and increase in air pollutants turned out to be nonsignificant for any of the pollutants in question.

The comparison of results between studies is rather difficult as they lack consistency in choice of pollutants and, especially, in terms of health outcomes. No clear association between changes in $\mathrm{PM}_{10}$ mass concentration, $\mathrm{SO}_{2}$, and $\mathrm{NO}_{2}$ and the prevalence of respiratory symptoms in asthmatic children was detected in the PEACE study (27). A significant interrelationship between hospital admissions for asthma in children aged $0-18$ years and exposure to $\mathrm{NO}_{2}\left(\mathrm{OR} 1.10,95 \%\right.$ CI 1.04-1.16) and $\mathrm{PM}_{10}(\mathrm{OR}$ $1.07,95 \%$ CI 1.03-1.12) was reported in Copenhagen (28).
Samoli et al. (1) have reported the highest increase in childhood hospital admissions for asthma exacerbation following increases in $\mathrm{PM}_{10}$ and $\mathrm{SO}_{2}$ concentrations in Athens while there was only limited evidence for relationship with $\mathrm{NO}_{2}$. A meta-analysis of 36 panel studies (4) has revealed a relationship between increased airborne $\mathrm{PM}_{10}$ and $\mathrm{NO}_{2}$ concentrations and asthma symptoms, whereas the association with cough was less clear. In the study (4), the symptoms were assessed comprehensively, including those which are not specific for asthma, such as cough or bronchitis. The well targeted questions used in the present study addressed asthma-specific symptoms and their association with air pollution appeared to be greater. In the combined category of breathing difficulties and wheezing a significant $7.3 \%$ increase occurred per $10 \mu \mathrm{g} / \mathrm{m}^{3}$ of suspended $\mathrm{PM}_{10}$ - compared to $2.8 \%$ found in the study by Weinmayr et al. (4) - and a significant $30.3 \%$ increase was observed per $10 \mu \mathrm{g} / \mathrm{m}^{3}$ of $\mathrm{NO}_{2}$ (vs. $3.1 \%$ ).

The significant adverse effect of air pollution on increased frequency of asthma symptoms in the preliminary results of the present study is in accord with other studies on the effect of short-term concentrations of $\mathrm{PM}_{10}$ and $\mathrm{NO}_{2}$ (3) or air pollution by $\mathrm{SO}_{2}$ which have a significant health impact on childhood asthma patients even at the recent relatively low concentrations (8). The data obtained will be further analyzed for the association between an airborne pollutant concentration increase and the delayed effect on the health of asthmatic children in lag days, as well as specific child/adolescent factors which may influence the health impact of air pollution, e.g. asthma control level, exposure to ETS or, conversely, regular sports activities.

\section{CONCLUSIONS}

This study of asthmatic children living in a highly polluted urban area found that increased concentrations of common air pollutants were associated with certain respiratory symptoms, such as breathing difficulties and wheezing and add-on medication use. For other asthma symptoms, the results were less consistent. More detailed analyses of the impact of air pollution on health are required in order to make a reliable assessment of public health conditions in highly exposed populations, as in the Ostrava region.

\section{Acknowledgements}

The study was supported by the Ministry of Health of the Czech Republic (grant No. NT 14608-3/2013 from the Internal Grant Agency of the Ministry of Health) and partially supported by the long-term strategic development financing of the Institute of Computer Science (RVO 67985807, Czech Republic).

\section{Conflict of Interests}

None declared

\section{REFERENCES}

1. Samoli E, Nastos PT, Paliatsos AG, Katsouyanni K, Priftis KN. Acute effects of air pollution on pediatric asthma exacerbation: evidence of association and effect modification. Environ Res. 2011 Apr;111(3):418-24.

2. Halonen JI, Lanki T, Yli-Tuomi T, Kulmala M, Tiittanen P, Pekkanen J. Urban air pollution, and asthma and COPD hospital emergency room visits. Thorax. 2008 Jul;63(7):635-41. 
3. Schildcrout JS, Sheppard L, Lumley T, Slaughter JC, Koenig JQ, Shapiro GG. Ambient air pollution and asthma exacerbations in children: an eight-city analysis. Am J Epidemiol. 2006 Sep 15;164(6):505-17.

4. Weinmayr G, Romeo E, De Sario M, Weiland SK, Forastiere F. Shortterm effects of PM10 and NO2 on respiratory health among children with asthma or asthma-like symptoms: a systematic review and meta-analysis. Environ Health Perspect. 2010 Apr;118(4):449-57.

5. Künzli N. Is air pollution of the 20th century a cause of current asthma hospitalisations? Thorax. 2012 Jan;67(1):2-3.

6. Laurent O, Pedrono G, Segala C, Filleul L, Havard S, Deguen S, et al. Air pollution, asthma attacks, and socioeconomic deprivation: a small-area case-crossover study. Am J Epidemiol. 2008 Jul 1;168(1):58-65.

7. Delfino RJ, Zeiger RS, Seltzer JM, Street DH, McLaren CE. Association of asthma symptoms with peak particulate air pollution and effect modification by anti-inflammatory medication use. Environ Health Perspect. 2002 Oct;110(10):A607-17.

8. Segala C, Fauroux B, Just J, Pascual L, Grimfeld A, Neukirch F. Shortterm effect of winter air pollution on respiratory health of asthmatic children in Paris. Eur Respir J. 1998 Mar;11(3):677-85.

9. Peters A, Dockery DW, Heinrich J, Wichmann HE. Short-term effects of particulate air pollution on respiratory morbidity in asthmatic children. Eur Respir J. 1997 Apr;10(4):872 -9.

10. Peters A, Dockery DW, Heinrich J, Wichmann HE. Medication use modifies the health effects of particulate sulfate air pollution in children with asthma. Environ Health Perspect. 1997 Apr;105(4):430-5.

11. Šlachtová H, Kůsová J. Health impacts of air pollution in the OstravaKarvina region. Ochrana ovzduší. 2008;(5-6):24-32. (In Czech.)

12. Act No. 201/2012 Coll., Air Protection Act of 2 May 2012. Sbírka zákonů ČR. 2012;Pt 69:2786-848. (In Czech.)

13. Blažek Z, Černikovský L, Černý E, Hrbek T, Keder J, Novák M, et al. Evaluation of operation of the smog warning and regulation system on the Czech Republic territory during winter season 2009-2010. Ochrana ovzduší. 2010;(3):13-20. (In Czech.)

14. Leonardi GS, Houthuijs D, Nikiforov B, Volf J, Rudnai P, Zejda J, et al. Respiratory symptoms, bronchitis and asthma in children of Central and Eastern Europe. Eur Respir J. 2002 Oct;20(4):890-8.

15. Kratěnová J, Puklová V. Monitoring of allergy diseases in children in Ostrava-Karviná region in 2006. Alergie [Internet]. 2011 [cited $2015 \mathrm{Sep}$ 15];13 Suppl 2:30-5. Available from: http:/www.tigis.cz/images/stories/ Alergie/2011/suppl_2_2011/5_kratenova.pdf. (In Czech.)
16. Sorkness CA, Schatz M, Li JT, Nathan RA, Murray JJ, Marcus P, et al. Assessing the relative contribution of the Asthma Control TestT and spirometry in predicting asthma control. J Allergy Clin Immunol. 2004 Feb;113(2 Suppl):S279. doi:10.1016/j.jaci.2004.01.480.

17. Schatz M, Sorkness CA, Li JT, Marcus P, Murray JJ, Nathan RA, et al Asthma Control Test: reliability, validity, and responsiveness in patients not previously followed by asthma specialists. J Allergy Clin Immunol. 2006 Mar;117(3):549-56.

18. Nathan RA, Sorkness CA, Kosinski M, Schatz M, Li JT, Marcus P, et al. Development of the asthma control test: a survey for assessing asthma control. J Allergy Clin Immunol. 2004 Jan;113(1):59-65.

19. Vondra V, Malý M, Vondrová I, Brejchová M. Results of Asthma Control Test (ACT). Alergie. 2006;8(4):285-90. (In Czech.)

20. Steadman RG. Norms of apparent temperature in Australia. Aust Meteorol Mag. 1994;43(1):1-16.

21. Fitzmaurice GM, Laird NM, Ware JH. Applied longitudinal analysis. 2nd ed. Hoboken: Wiley; 2011.

22. Stroup WW. Generalized linear mixed models: modern concepts, methods and applications. Boca Raton: CRC Press; 2013.

23. Kotlík B. Data analysis of PM10 at selected stations in the city of Ostrava for the period 2006 to 2011. Ochrana ovzduší. 2012;(6):19-24. (In Czech.)

24. Sázelová P, Kasicka V, Koval D, Kilár F, Knopp D, Peltre G. Analysis of water extracts from airborne dust samples by capillary isotachophoresis. J Chromatogr A. 2003 Mar 21;990(1-2):303-9.

25. Delfino RJ, Zeiger RS, Seltzer JM, Street DH. Symptoms in pediatric asthmatics and air pollution: differences in effects by symptom severity, anti-inflammatory medication use and particulate averaging time. Environ Health Perspect. 1998 Nov;106(11):751-61.

26. Hruška L, Samiec M, Svobodník J, Matoláková R, Foldynová I. Socioeconomic atlas of the Moravian-Silesian Region. Ostrava: ACCENDO - Center for Science and Research; 2012. (In Czech.)

27. Roemer W, Hoek G, Brunekreef B. Pollution effects on asthmatic children in Europe, the PEACE study. Clin Exp Allergy. 2000 Aug;30(8):1067-75.

28. Iskandar A, Andersen ZJ, Bønnelykke K, Ellermann T, Andersen KK, Bisgaard $\mathrm{H}$. Coarse and fine particles but not ultrafine particles in urban air trigger hospital admission for asthma in children. Thorax. 2012 Mar;67(3):252-7.

Received September 3, 2015 Accepted in revised form November 29, 2015 